\title{
Green Synthesis of Silver Nanoparticles Using the Flower Extract of Abelmoschus esculentus for Cytotoxicity and Antimicrobial Studies
}

\section{Sandhanasamy Devanesan (D) Mohamad S AISalhi}

Department of Physics and Astronomy, College of Science, King Saud University, Riyadh, I I45I, Kingdom of Saudi Arabia
Correspondence: Mohamad S AISalhi Email malsahi@ksu.edu.sa
Background: Abelmoschus esculentus (L.) Moench, an economically important malvaceous vegetable crop popularly known as okra, is used in various culinary preparations and is rich in vitamins, minerals, and nutrients. The biological properties of okra flowers in relation to nanoparticle synthesis have not yet been reported.

Materials and Methods: In the current study, silver nanoparticles (AgNPs) were synthesized using extracts of the flowers of $A$. esculentus. The characteristics of the AgNPs were studied using a UV-vis spectrometer, Fourier transmission infrared spectrophotometer (FTIR), X-ray diffractometer (XRD), scanning electron microscope (SEM), transmission electron microscope (TEM) and energy dispersive X-ray spectrometer (EDX). Antibacterial activity screening was performed using the agar well diffusion method, and cytotoxicity and cell viability studies were conducted using a 3-(4,5-dimethylthiazol-2-yl)-2,5-diphenyltetrazolium bromide (MTT) assay. Results: The synthesized AgNPs were spherical and ranged in size from 5.52 to $31.96 \mathrm{~nm}$, with an average size of $16.19 \mathrm{~nm}$, as determined by UV-vis spectroscopy, FTIR, XRD, TEM and EDX. A. esculentus flower extract-mediated silver nanoparticles (AME-AgNPs) exhibited excellent activities in vitro studies, particularly in vitro cytotoxic and antiproliferative studies against cancer cell lines, such as the TERT-4 and A-549 cell lines. The antibacterial effects on the Gram-positive pathogens Bacillus subtilis, Staphylococcus aureus, Staphylococcus epidermidis, and Streptococcus pyogenes and the Gram-negative pathogens Klebsiella pneumoniae, Escherichia coli, Pseudomonas aeruginosa, Proteus vulgaris, Salmonella typhimurium and Shigella sonnei were tested. The minimum inhibitory concentration (MIC) and minimum bactericidal concentration (MBC) values varied with the bacterial strain. The $\mathrm{IC}_{50}$ values of the synthesized NPs for the tested cell lines were close to that of a standard drug.

Conclusion: Compared to other NPs the NPs synthesized in this study were smaller in size and exhibited a higher level of antibacterial activity, cytotoxicity and apoptosis at minimal concentrations, and this is the first study on okra flower-induced anticancer and antimicrobial activities.

Keywords: Abelmoschus esculentus, silver nanoparticles, okra green pods, cell lines and cytotoxicity

\section{Introduction}

Abelmoschus esculentus L., commonly known as "lady's fingers," “okra," or "bhindi”, is an important vegetable crop cultivated in many countries. In the intensive search for a good biological agent for synthesizing metal nanoparticles, several biological entities from microbes to plants and animal products have been given much attention. ${ }^{1-3}$ Among the different bio-tools used to produce nanoparticles, plant products are 
given high priority. ${ }^{46}$ Green synthesis routes using various plants parts have produced active materials that have greater potential against gram-positive and gram-negative microorganisms and different cancer cell lines and exhibit higher antioxidant effects than those produced by chemical and thermal physical methods. ${ }^{7-9}$ Of the different plant products, the flowers of plants have received much attention for utilization. The synthesis of biomedically important NPs (nanoparticles) using floral extracts has several advantages compared with other biological methods. ${ }^{10}$ Because of their unique chemical properties, NPs fabricated by a flowermediated procedure are more efficient than those synthesized using other biological materials. ${ }^{11,12}$ The flowers of many plants contain diverse secondary compounds that function as reducing and stabilizing agents and as precursor molecules involved in the formation of NPs. ${ }^{13}$

Numerous studies have reported the production or synthesis of AgNPs by microwave-assisted, phase transfer, electrochemical, and photochemical methods, but these synthesis steps require toxic chemicals. The green synthesis of AgNPs using medicinal plants does not require any toxic materials, is simple and ecofriendly, and produces NPs with high efficacy. Plants contain many phytoconstituents that give numerous benefits, including antimicrobial, anticancer, and antioxidant activities, and the synthesis of AgNPs with plant sources improves the efficacy with a smaller quantity. A previous report provided remarkable information on plant-mediated AgNPs. ${ }^{14,15}$

The extract of jasmine flowers has been reported to act as a capping and stabilizing agent in NP synthesis. ${ }^{16}$ Flowerderived AgNPs exhibit good antibacterial, antioxidant, and insecticidal properties for different applications. ${ }^{12}$ Silver, zinc and gold nanoparticles produced with the flower extract of Rhanterium epapposum are effective cytotoxic and antifungal agents. ${ }^{17}$ However, no reports on the production of silver NPs using the flowers of okra (A. esculentus (L.) Moench), which belongs to the family Malvaceae, are available. Okra, known as lady's fingers in English, bhindi in Southeast Asia and bamia in the Middle East, is a vegetable plant with rich medicinal properties. Okra is a vegetable with a good table value merged with medicinal and pharmacological applications. ${ }^{18}$ Gold nanoparticles synthesized using the pulp extract of $A$. esculentus were reported to have good anticancer and antimicrobial effects. ${ }^{19} A$. esculentus-based cadmium oxide nanoparticles exhibited good antimicrobial activity. ${ }^{20}$ Okra plant extract-mediated biosynthesized nickel oxide nanoparticles showed cytotoxicity and had antibacterial properties. ${ }^{21}$ The different parts of okra, including the flowers, fruits and seeds, contain polyphenolic compounds, catechins, flavanols, tannins and many minerals. ${ }^{22}$ The novelty of this study is that it is the first report of the synthesis of AgNPs using okra flowers, and minimal NP sizes were achieved. A minimal quantity of AME-AgNPs $(5 \mu \mathrm{L})$ was used as the initial concentration, and their effects against the tested organisms were good, with more than $60 \%$ of the tested organisms dying. The okra flower is widespread, and the flowers of A. esculentus, which are rich in reducing agents, remain unstudied; therefore, it was chosen as a biogenic agent for synthesizing AgNPs in this study.

\section{Materials and Methods}

All the experimental chemicals used were purchased from Sigma-Aldrich (authorized dealer Saudi Arabia) and had a high purity level (the purity and quality of the chemicals were always a focus when purchasing the chemicals).

\section{Preparation of Silver Nanoparticles}

Currently, Saudi Arabia encourages small farmers to switch to organic farming to cultivate vegetables and other foodstuffs. Fresh A. esculentus flowers were collected in the morning from an organic agriculture farm in Al-Kharj, Riyadh Province, Saudi Arabia. Plant authentication and nomenclature studies were performed at the Herbarium of King Saud University. Further study approvals were not required according to regional guidelines. The freshly collected flowers ( 250 grams) were dried at room temperature, and the dried flowers were blended as a fine powder. Five grams of the powder was soaked in $100 \mathrm{~mL}$ of double distilled water (DH2O) for $24 \mathrm{~h}$. The collected aqueous flower extract (AME) was filtered using Whatman No 1 filter paper, and the extract was dark black in color. Then, $1 \mathrm{mM}$ silver nitrate (AgNO3) was added to $250 \mathrm{~mL}$ of double distilled water and thoroughly mixed until $\mathrm{AgNO}_{3}$ was dissolved. Then, $5 \mathrm{~mL}$ of AME was added and thoroughly mixed. The mixed solution was observed, and the colorless solution turned dark brown in color in $72 \mathrm{~h}$, indicating the formation of AME-AgNPs (Supplementary Figure 1). This change may be due to the excitation of the surface plasmon resonance of the synthesized AgNPs. Then, the colorchanged aqueous solution was collected in sterilized $50 \mathrm{~mL}$ centrifuge tubes and centrifuged at $15000 \mathrm{rpm}$ for $15 \mathrm{~min}$ utes. The process was repeated 3 times with distilled water to maintain the purity of the synthesized AME-AgNPs. The precipitate was placed in a biosafety shaking incubator at $38^{\circ} \mathrm{C}$, and the NPs were collected once completely dried. The remaining flower extract was stored at $4^{\circ} \mathrm{C}$ for further investigation. 


\section{Characterization of Synthesized Silver Nanoparticles}

A UV-vis spectrophotometer (Perkin Elmer, LS 55) was used to characterize the synthesized AME-AgNPs. The components in the extract were characterized using a Shimadzu FTIR Prestige 21 spectrophotometer (Shimadzu Corporation, Kyoto, Japan) in the $\mathrm{KBr}$ phase $(1: 100))^{1,2,5}$ The spectrum was recorded in the range of 400-4000 cm-1. The XRD pattern of the synthesized AME-Ag NPs was constructed using spectral data collected with a Philips PW-1830 X-ray diffractometer. A scanning electron microscope (SEM) (JEOL, Japan) and energy dispersive X-ray spectroscopy system (EDAX Inc.) were used. The AgNPs were observed by transmission electron microscopy (TEM) (JEOL, Japan).

\section{Antimicrobial Study}

Bacterial Strain Preparation

Different concentrations of the synthesized extractmediated AgNPs (5, 10, 25, 50 and $100 \mu \mathrm{L}$ ) were tested against gram-positive bacteria, such as $B$. subtilis (MTCC 441), S. aureus (ATCC 29213), S. epidermidis (MTCC 3615) and S. pyogenes (ATCC 29213), and the gramnegative pathogens $K$. pneumoniae (G455), E. coli (ATCC 25922), P. aeruginosa (ATCC 27584), P. vulgaris (ATCC 8427), S. typhimurium (ATCC 14028) and S. sonnei.

\section{Agar Well Diffusion Method}

The antibacterial activity of the AME-AgNPs against the selected bacterial strains was determined using the agar well diffusion method. A subculture of each bacterial strain, $200 \mu \mathrm{L}$, equivalent to $10^{6} \mathrm{CFU} / \mathrm{mL}$, was homogeneously spread on the surface of a Petri dish containing Mueller-Hinton agar (MHA) (Merck, Germany) using a sterile cotton swab with the help of a sterile gel borer. Six wells with a $10 \mathrm{~mm}$ diameter were made on the Mueller-Hinton agar with the bacterial strains. The wells were loaded with different doses $(5,10,25,50$ and 100 $\mu \mathrm{L})$ of the aqueous extract of the AME-AgNPs diluted from the stock $(100 \mu \mathrm{g} / \mathrm{mL})$ with sterile water. The plates were incubated at $37^{\circ} \mathrm{C}$ for $24 \mathrm{~h}$, and then, the zone of inhibition was measured around the wells after incubation. The positive control used was ciprofloxacin $(1 \mathrm{mg} / \mathrm{mL})$.

The MIC and MBC of the AME-AgNPs were determined following the CLSI standard. ${ }^{23}$ For the MIC, a microdilution method using Mueller Hinton broth medium (MHB) was used. The MIC of the AME-AgNPs against the test bacteria was determined by resazurin staining in a 96-well microtiter plate. Ten microliters of the overnight-grown culture $\left(10^{6} \mathrm{CFU} / \mathrm{mL}\right)$ was inoculated into each well of a 96-well microtiter plate, and the control well contained ciprofloxacin. The cultures were then allowed to grow overnight in a bacteriological incubator. The concentration associated with no color change was taken as the MIC.

MBC estimation was performed using Mueller-Hinton agar medium (MHA). The concentrations of the bacterial inocula were adjusted to $10^{6} \mathrm{CFU} / \mathrm{mL}$. One hundred microliters of a stock solution of $500 \mu \mathrm{g} / \mathrm{mL}$ AMEAgNPs was diluted twofold. Ten microliters of the overnight-grown culture $\left(10^{6} \mathrm{CFU} / \mathrm{mL}\right)$ was inoculated in each well of a 96-well microtiter plate containing the twofolddiluted AME-AgNPs and the control group. For MBC determination, the test suspension from each well of the microtiter plates was placed on an MHA plate. The plates were incubated at $37^{\circ} \mathrm{C}$ for $24 \mathrm{~h}$. The lowest concentration with no visible growth on the MHA plate was taken as the $\mathrm{MBC}$ value.

\section{MTT Assay}

The cytotoxicity of the synthesized nanoparticles was assessed by an MTT assay following the method of Mosmann et $\mathrm{al}^{24}$ with modifications. For the MTT assay, three cancer cell lines were obtained from ATCC (USA). The chosen cell lines included the lung cancer cell line A-549 and mesenchymal cell line TERT-4. The cell lines were grown in DMEM supplemented with fetal bovine serum $(10 \%)$, sodium bicarbonate $(0.2 \%)$, and an antibiotic-antimycotic solution (1 mL/100 mL of medium). In brief, the A-549 and TERT-4 cells (500 cells/well) were seeded in 96-well tissue culture plates and incubated overnight in a $\mathrm{CO}_{2}$ incubator for attachment. Then, the medium was aspirated and replaced with media containing different concentrations $(1-100 \mu \mathrm{g} / \mathrm{mL})$ of the synthesized nanoparticles. The cells were treated for $24 \mathrm{~h}$. Then, MTT $(10 \mu \mathrm{L} /$ well containing $100 \mu \mathrm{L}$ of the cell suspension; $5 \mathrm{mg} / \mathrm{mL}$ of the stock in PBS) was added to each well and incubated for $4 \mathrm{~h}$. Then, the reaction mixture was carefully removed, and $200 \mu \mathrm{L}$ of DMSO was added to each well by pipetting up and down several times until the contents were homogenized. After 10 minutes, the color was read at $550 \mathrm{~nm}$ using an ELISA reader. The untreated control was also run simultaneously under identical conditions and served as a control. The $\mathrm{IC}_{50}$ value for the AME-AgNPs was also determined. 


\section{Morphological Changes in the Cells}

To determine the morphological changes in the cells, the cells (TERT-4 and A-549) were seeded in a 92-well plate at a concentration of $1 \times 10^{4}$ cells/well and incubated for 24 h. When the cells were completely attached, the cells were washed with phosphate-buffered saline ( $\mathrm{pH}$ 7.4). Then, different concentrations of AME-AgNPs $(1-100 \mu \mathrm{g} / \mathrm{mL})$ were added to each corresponding well. The plate was incubated for $48 \mathrm{~h}$, after which the supernatant was aspirated. The cells were then washed with PBS ( $\mathrm{pH}$ 7.4). After that exposure, the morphological changes in each group of cells induced by the nanoparticles were observed with a phase contrast inverted microscope at $20 \times$ magnification.

\section{Statistical Analysis}

The average size of the NPs was determined from the TEM images using the ImageJ software. We used GraphPad to calculate the MTT cell viability $\left(\mathrm{EC}_{50)}\right.$ and standard deviation. The statistical analyses were performed with a significance of $p<0.05$.

\section{Results and Discussion}

The formation of AgNPs was visually noted by the development of a dark brown color in the conical flask containing the AME-AgNPs (Figure 1A-C)). The color also changed during the synthesis of AgNPs using different plant extracts in our previous studies. ${ }^{1,2,4,6} \mathrm{UV}$-Vis absorption spectroscopy was used to characterize the optical properties of the AME-AgNPs. The absorption spectrum exhibited a peak at $430 \mathrm{~nm}$ in $24 \mathrm{~h}$ to $72 \mathrm{~h}$ (Figure 2A-D), confirming the

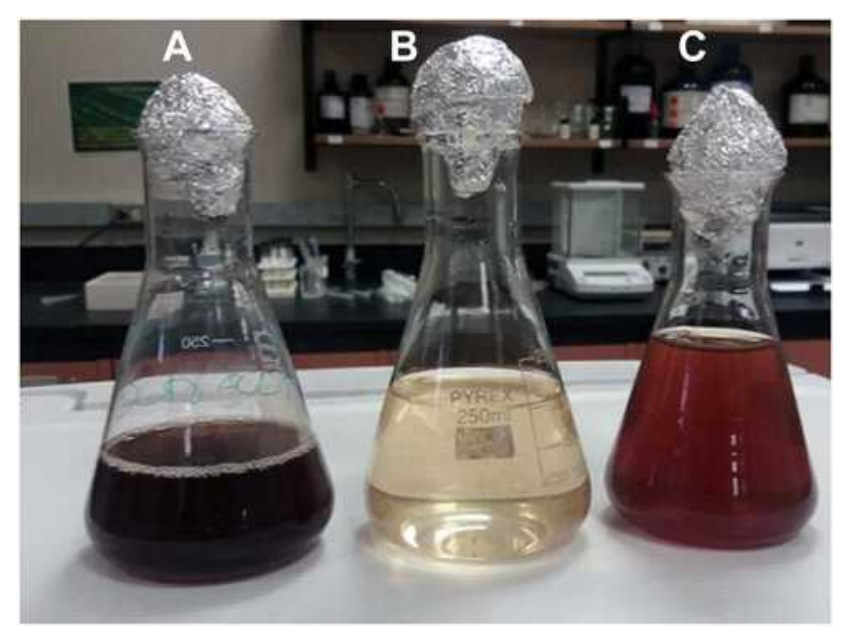

Figure I Photograph showing the change of colour due to AME-AgNPs formation. (A) AME flower extract, (B) mixed aqueous solution of AME flower extract and $\mathrm{AgNo}_{3}$ and (C) formation of $\mathrm{AgNPs}$. formation of silver nanoparticles. The UV-vis spectra were monitored at different time intervals of $24 \mathrm{~h}, 48 \mathrm{~h}$ and 72 h. Using a mass mathematical model, ${ }^{25}$ the particle size of the synthesized NPs was found to be $13.45 \mathrm{~nm}$. A previous report provided evidence of the formation of AgNPs using the flower extract of Zephyranthes rosea. ${ }^{26}$

The FTIR results indicated the presence of different functional groups in the extract that acted as reducing and stabilizing agents during the synthesis process of the NPs. The FTIR spectra of the AME extract and AME-AgNPs are shown in Figure 3A and B, respectively. The AME extract exhibited bands at 1054.13, 1329, 1635.12 and $2925 \mathrm{~cm}^{-1}$, whereas the AME-AgNPs exhibited bands at 1066.42, 1232, 1641.17, 2368.21 and $2918 \mathrm{~cm}^{-1}$. Huge differences were observed between the relative intensities of the AME extract and the AME-AgNPs, and the spectrum shoulder was slightly shifted. In the AME-AgNPs spectrum, the peak at $1066.42 \mathrm{~cm}-1$ was attributed to the stretching vibration of the $\mathrm{C}-\mathrm{O}$ functional group in alcohols/phenols. The absorption band at $1032 \mathrm{~cm}^{-1}$ indicated the presence of phenolic groups. The absorption peak observed at $1641.17 \mathrm{~cm}^{-1}$ was attributed to $\mathrm{C}=\mathrm{C}$ bond stretching and indicated the formation of alkenes and aromatic rings. The sharp spectral peak at $2368.21 \mathrm{~cm}-1$ indicated the presence of $\mathrm{NH}^{2+} / \mathrm{NH}^{3+}$ in the peptide bonds of protein molecules. The spectral peak at $2918.35 \mathrm{~cm}-1$ was assigned to a medium single-bonded $\mathrm{C}-\mathrm{H}$ alkane group. The FTIR spectra confirm the presence of active biomolecules in the plant extract, which acted as capping and reducing agents, reducing $\mathrm{Ag}^{+}$to $\mathrm{Ag}^{0}$. 8,27

$\mathrm{X}$-ray diffraction (XRD) is one of the most extensively used techniques for the characterization of NPs. The X-ray diffraction pattern of $0.01 \mathrm{~mol} / \mathrm{L}$ AME-AgNPs exhibited four distinct diffraction peaks at $38.24^{\circ}, 44.13^{\circ}, 77.55 .11^{\circ}$ and $84.32^{\circ}$ corresponding to the $111,200,220$ and 311 planes, respectively (Figure 4). The sharp peak at $38.24^{\circ}$ related to the 111 plane shows that the sample was pure without any major impurities. This Bragg reflection plane corresponds to the face-centered cubic ( $\mathrm{fcc}$ ) phase of silver, as previously reported. ${ }^{28}$ The characteristics of the XRD spectrum of the NPs referenced to the JCPDS (Joint Committee on Powder Diffraction Standards - Card No. 05-0667) showed that the material had a crystalline nature. Because the crystallite size is reflection of the coherent diffraction domain, it is not necessarily the same as the particle size. ${ }^{29}$ The crystallite size was calculated using Scherrer's formula, $\mathrm{D}=\mathrm{K} \lambda / \beta \cos \theta,{ }^{30}$ and the average size of the AME-AgNPs was $20.12 \mathrm{~nm}$ based on the intense peak corresponding to the 111-plane located at $38.24^{\circ}$, as reported earlier for silver nanoparticles. ${ }^{31,32}$ 


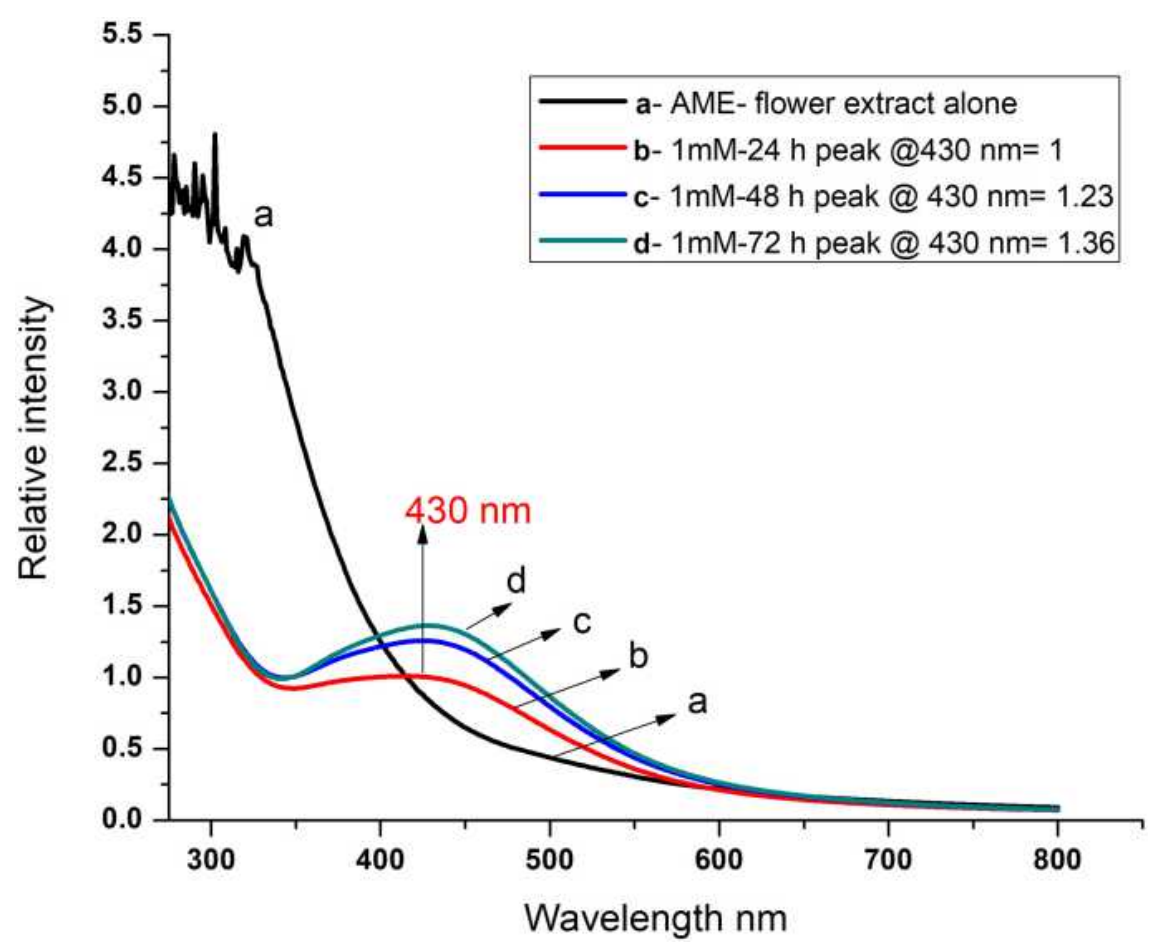

Figure 2 UV-vis spectrum of I mM AgNPs with different interval times 24 to $72 \mathrm{~h}$. (a) AME flower extract spectra, (b) $24 \mathrm{~h}$ spectra of record for mixed aqueous solution of AME flower extract and $\mathrm{AgNo}_{3}$, (c) $48 \mathrm{~h}$ spectra of record for mixed aqueous solution of $\mathrm{AME}$ flower extract and $\mathrm{AgNo}_{3}$ and (d) $72 \mathrm{~h}$ spectra of record for mixed aqueous solution of $\mathrm{AME}$ flower extract and $\mathrm{AgNo}_{3}$.

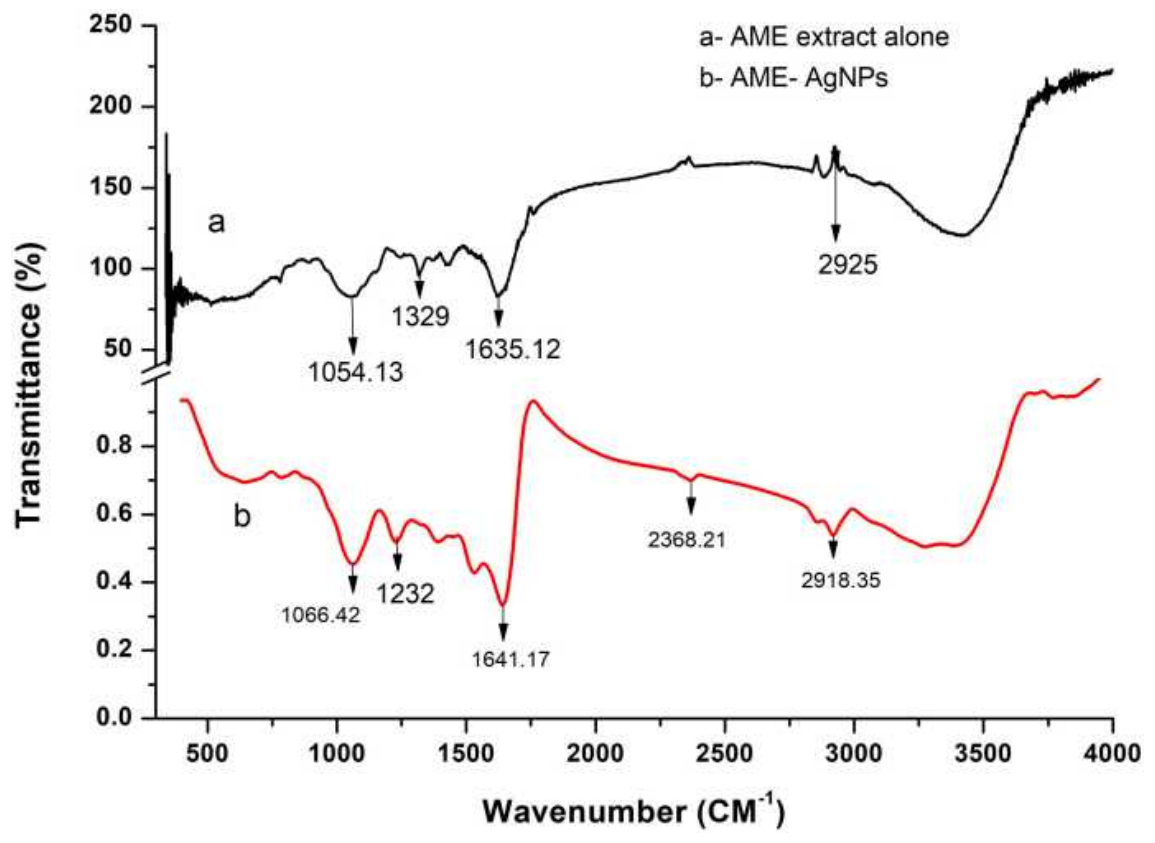

Figure 3 FTIR spectrum recorded for (a) AME-flower powder and (b) AgNPs synthesized using AME flower extract.

An SEM-EDX analysis of the surface morphology of the AME-AgNPs synthesized using the flower extract of okra (Figure 5) revealed the presence of nanoparticles with different morphologies, although a predominance of spherical- elliptical NPs of different sizes was observed. Some aggregation was also detected, and most of our analysis results showed separate particles with spherical shapes. Few particles attached to each other, because the sample preparation 


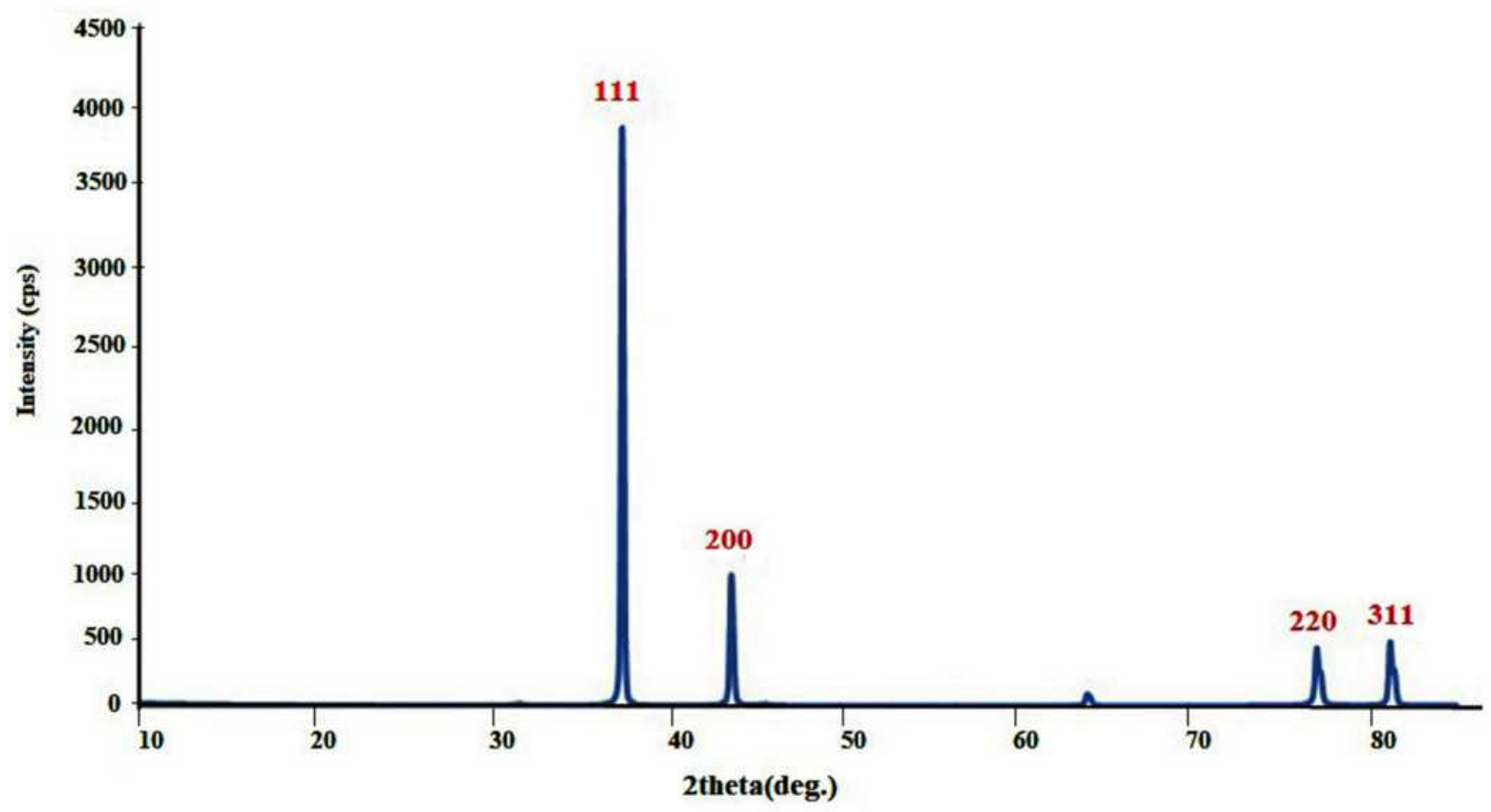

Figure 4 XRD spectrum of AgNPs synthesized using AME-flower extract.

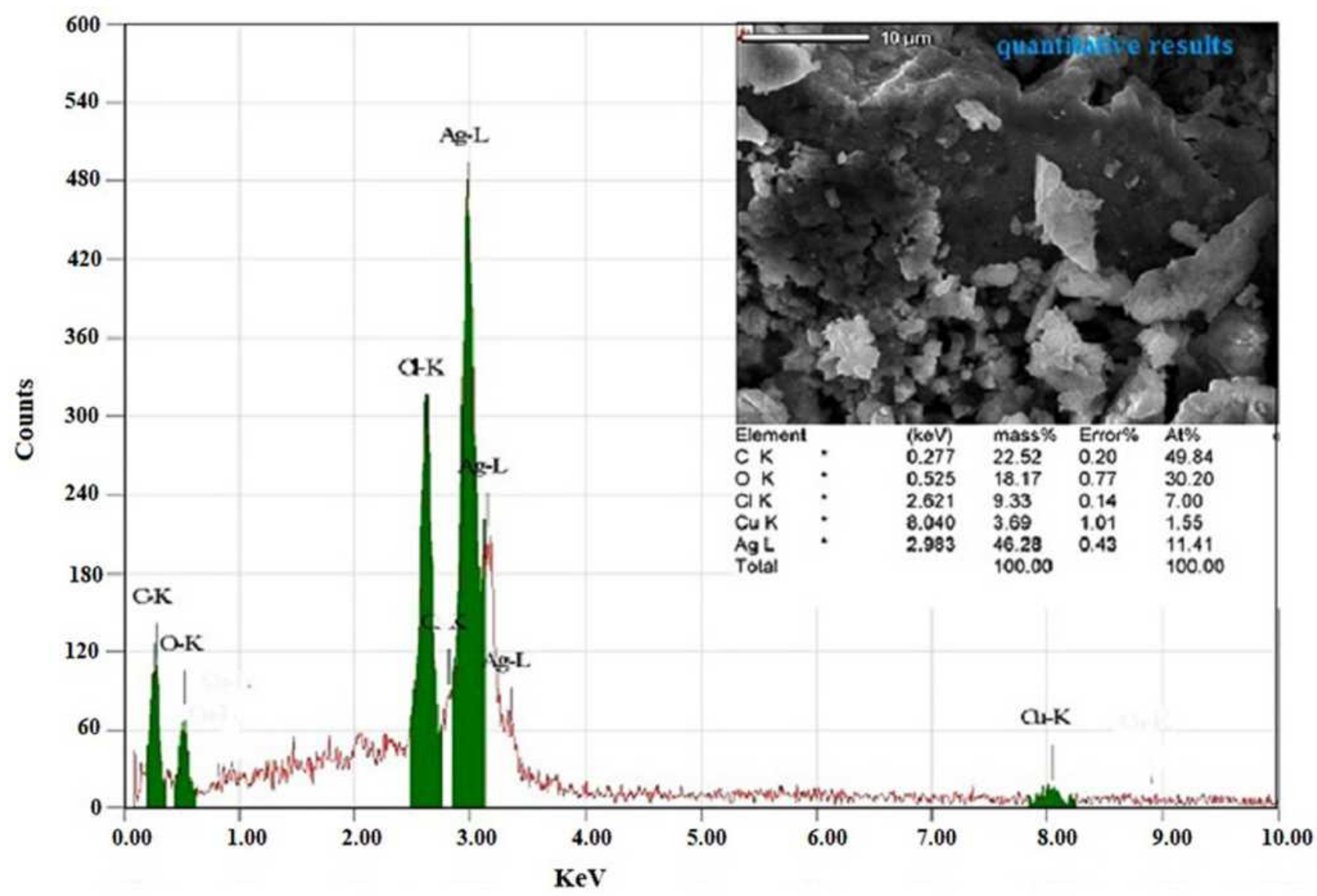

Figure 5 SEM micrograph of AgNPs synthesized using okra flower extract (right top corner) and energy dispersive X-ray spectrum of AME-AgNPs (bottom). 
resulted in NPs with rough surface areas, or the region selected for analysis had NPs with rough surfaces. ${ }^{33,34}$ The elemental composition analyzed by EDX spectroscopy indicated the presence of $\mathrm{C}, \mathrm{O}, \mathrm{K}, \mathrm{Cl}, \mathrm{Cu}$, and $\mathrm{Ag}$, and their mass percentages were $22.52,18.17,9.33,3.69$ and 46.28 , respectively. Of the elements, silver exhibited the highest perfect peak, indicating that the synthesized silver nanoparticles were pure.

TEM images of the AME-AgNPs indicated that the nanoparticles were spherical in shape with a size range between 5.52 and $24.65 \mathrm{~nm}$ (Figure 6A-D) and an average particle size of $18.24 \mathrm{~nm}$, which was close to the size of the NPs calculated from the XRD result. The TEM image showed the agglomeration of small grains and dispersed nanoparticles with the face-centered cubic (fcc) crystalline structure of metallic silver, as previously reported. ${ }^{34,35}$

\section{Antibacterial Action of the AME-AgNPs}

The activities of the synthesized AME-AgNPs against six Gram-negative and four Gram-positive bacterial pathogens were evaluated by the agar well diffusion method (Table 1 ,
Figures 7 and 8). Different doses of the AME-AgNPs, viz., $5 \mu \mathrm{L}, 10 \mu \mathrm{L}, 25 \mu \mathrm{L}, 50 \mu \mathrm{L}$, and $100 \mu \mathrm{L}$, were taken from a stock solution with a concentration of $100 \mu \mathrm{g} / \mathrm{mL}$. The antibacterial action was found to be dose dependent and varied for the different bacterial strains. The inhibitory effect of the NPs on the gram-negative bacteria was more pronounced than that on the Gram-positive bacteria. ${ }^{36}$ At a dose of $100 \mu \mathrm{L}, P$. vulgaris was the most inhibited LBS Gram-negative bacterium $(16 \pm 1.0 \mathrm{~mm})$, followed by $K$. pneumoniae $(14 \pm 0.5 \mathrm{~mm})$ and $S$. sonnei $(14 \pm 0.7 \mathrm{~mm})$. The inhibition activity of the AME-AgNPs against E. coli, and P. aeruginosa at a $100 \mu \mathrm{L}$ dosage of AME-AgNPs $(11.0 \pm 1.0 \mathrm{~mm})$ was low. Among the Grampositive bacteria, $S$. aureus and $S$. pyogenes exhibited the maximum inhibition zone diameter $(13.0 \pm 1.2 \mathrm{~mm})$ at a dose of $100 \mu \mathrm{L}$. The Gram-positive bacteria $S$. subtilis and $S$. epidermis were minimally inhibited $(12 \pm 1.0 \mathrm{~mm})$. According to Xuan et al, an antibacterial ring diameter of less than $5 \mathrm{~mm}$ indicates weak resistance, and a diameter of greater than $10 \mathrm{~mm}$ corresponds to strong resistance. ${ }^{37}$ In this study, the antibacterial action of the synthesized
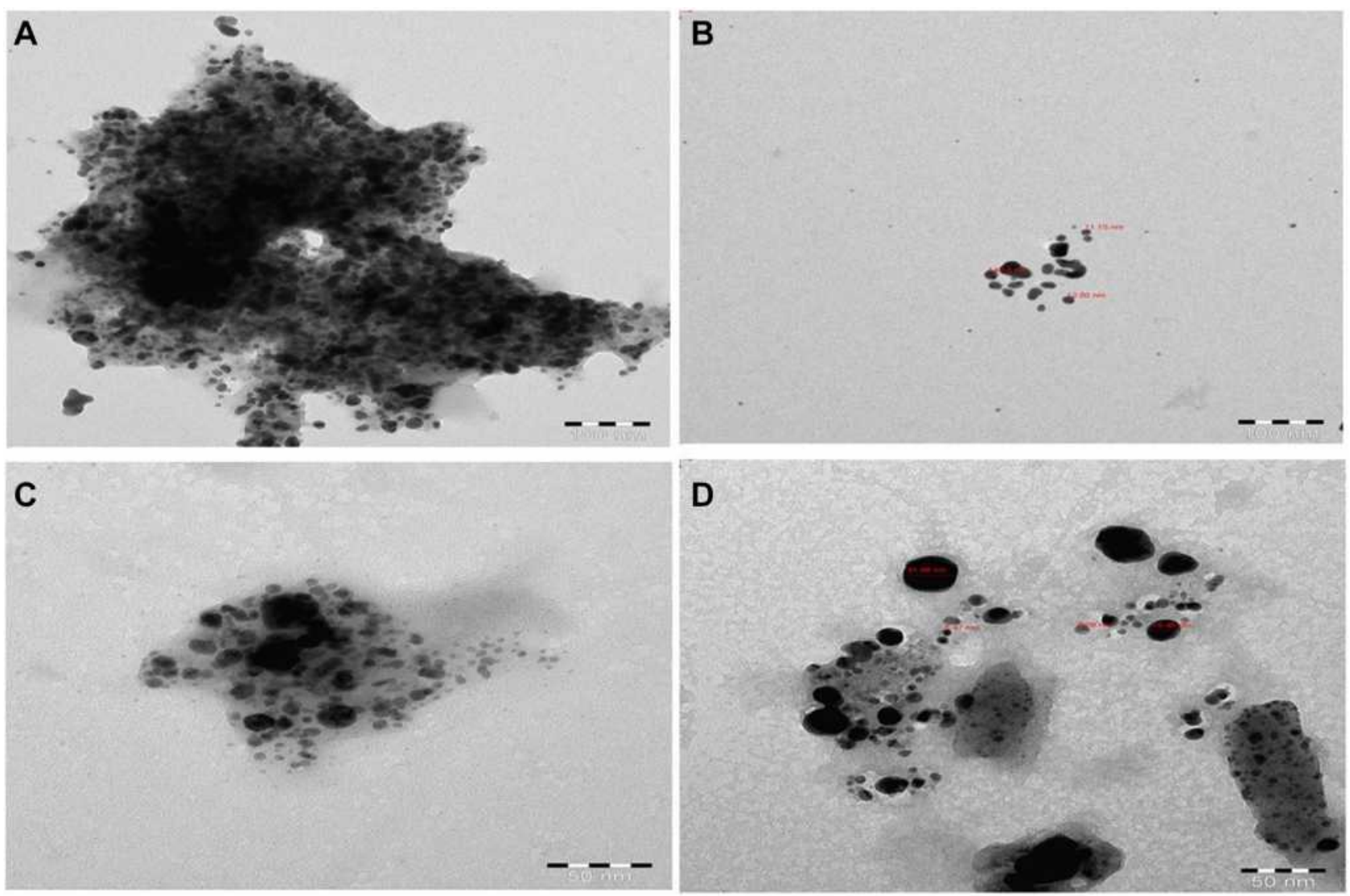

Figure 6 Micrograph showing the TEM image of AME-AgNPs with different magnifications 100 and $50 \mathrm{~nm}$. (A) $100 \mathrm{~nm}$ without labels, (B) $100 \mathrm{~nm}$ labeled with particles sizes, (C) $50 \mathrm{~nm}$ without labels and (D) $50 \mathrm{~nm}$ labeled with particles sizes. 
Table I Inhibitory Effect of AME-AgNPs with Different Bacterial Strains (Six Gram Negative and Four Gram Positive) and Control Drug for Ciprofloxacin

\begin{tabular}{|c|c|c|c|c|c|c|c|c|}
\hline \multicolumn{9}{|c|}{ Diameter of Zone of Inhibition in $\mathrm{mm}$ (Mean \pm SD) for Different Doses $(\mu \mathrm{g} / \mathrm{mL})$ AME-AgNPs } \\
\hline Bacterial strains & Control & 5 & 10 & 25 & 50 & 100 & $M I C[\mu g / m L ~ N P s]$ & $M B C[\mu g / m L ~ N P s]$ \\
\hline K. pneumoniae & 18 & $4 \pm 1.2$ & $6 \pm 0.5$ & $10 \pm 0.5$ & $11 \pm 0.5$ & $14 \pm 0.5^{*}$ & $105 \pm 3.0$ & $180 \pm 6.0$ \\
\hline E. coli & 20 & $5 \pm 1.0$ & $7 \pm 0.8$ & $8 \pm 1.0$ & $10 \pm 0.9$ & $13 \pm 1.6^{*}$ & $65.5 \pm 5.6$ & $110 \pm 10.0$ \\
\hline P. aeruginosa & 21 & $6 \pm 1.0$ & $8 \pm 1.0$ & $9 \pm 0.7$ & $10 \pm 0.7$ & $11 \pm 1.0 *$ & $75.5 \pm 6.0$ & $105 \pm 8.0$ \\
\hline P. vulgaris & 20 & $6 \pm 0.5$ & $8 \pm 1.0$ & $9 \pm 1.8$ & $13.1 \pm 1.0$ & $16 \pm 0.5^{*}$ & $45.5 \pm 5.0$ & $56.5 \pm 5.0$ \\
\hline S. typhi & 14 & $5 \pm 1.0$ & $8 \pm 0.7$ & $9 \pm 1.0$ & $11 \pm 0.5$ & $12 \pm 1.5^{*}$ & $150.0 \pm 8.0$ & $212 \pm 10.0$ \\
\hline S. sonnei & 18 & $7 \pm 0.5$ & $8 \pm 0.6$ & $10 \pm 1.2$ & $\mathrm{II} \pm 0.7$ & $14 \pm 0.7^{*}$ & $90.0 \pm 6.0$ & $100 \pm 5.0$ \\
\hline B. subtilis & 20 & $4 \pm 1.0$ & $5 \pm 0.6$ & $7 \pm 0.8$ & $9 \pm 1.0$ & $12 \pm 1.0 *$ & $180 \pm 9.0$ & $220 \pm 3.0$ \\
\hline S. aureus & 17 & $5 \pm 1.0$ & $8 \pm 1.0$ & $10 \pm 0.7$ & $12 \pm 0.5$ & $13 \pm 1.0 *$ & $85 \pm 5.0$ & $90 \pm 7.0$ \\
\hline S. epidermis & 18 & $5 \pm 1.0$ & $7 \pm 0.7$ & $8 \pm 1.0$ & $10 \pm 1.0$ & $12 \pm 1.2 *$ & $150 \pm 5.0$ & $165 \pm 4.0$ \\
\hline S. pyogenes & 20 & $5 \pm 1.0$ & $6 \pm 1.0$ & $8 \pm 1.0$ & $10 \pm 1.0$ & $13 \pm 1.2 *$ & $150 \pm 5.0$ & $59 \pm 2.0$ \\
\hline
\end{tabular}

Note: *Indicates significant at different concentration levels $\mathrm{p}<0.05$.

NPs strongly inhibited all the tested bacterial strains. The minimum inhibitory concentration of the AME-AgNPs against the selected bacterial strains (Table 1) was maximal for B. subtilis $(180 \mu \mathrm{g} / \mathrm{mL})$, and the minimum MIC value was observed for $P$. vulgaris $(45 \mu \mathrm{g} / \mathrm{mL})$. The $\mathrm{MBC}$ of the AME-AgNPs that killed $100 \%$ of the bacterial population, which did not exhibit any viable bacterial growth, was $220 \mu \mathrm{g} / \mathrm{mL}$ for $B$. subtilis, and the minimum was observed for $P$. vulgaris $(56.5 \mu \mathrm{g} / \mathrm{mL})$. The varying levels of the MIC and MBC values may be due to the intrinsic tolerance levels of each bacterial strain, as previously reported. ${ }^{38}$

As previously reported, the antibacterial properties of NPs are caused by the partial dissolution of the bacterial cell wall due to charge effects between the negatively charged cell wall and the positively charged silver
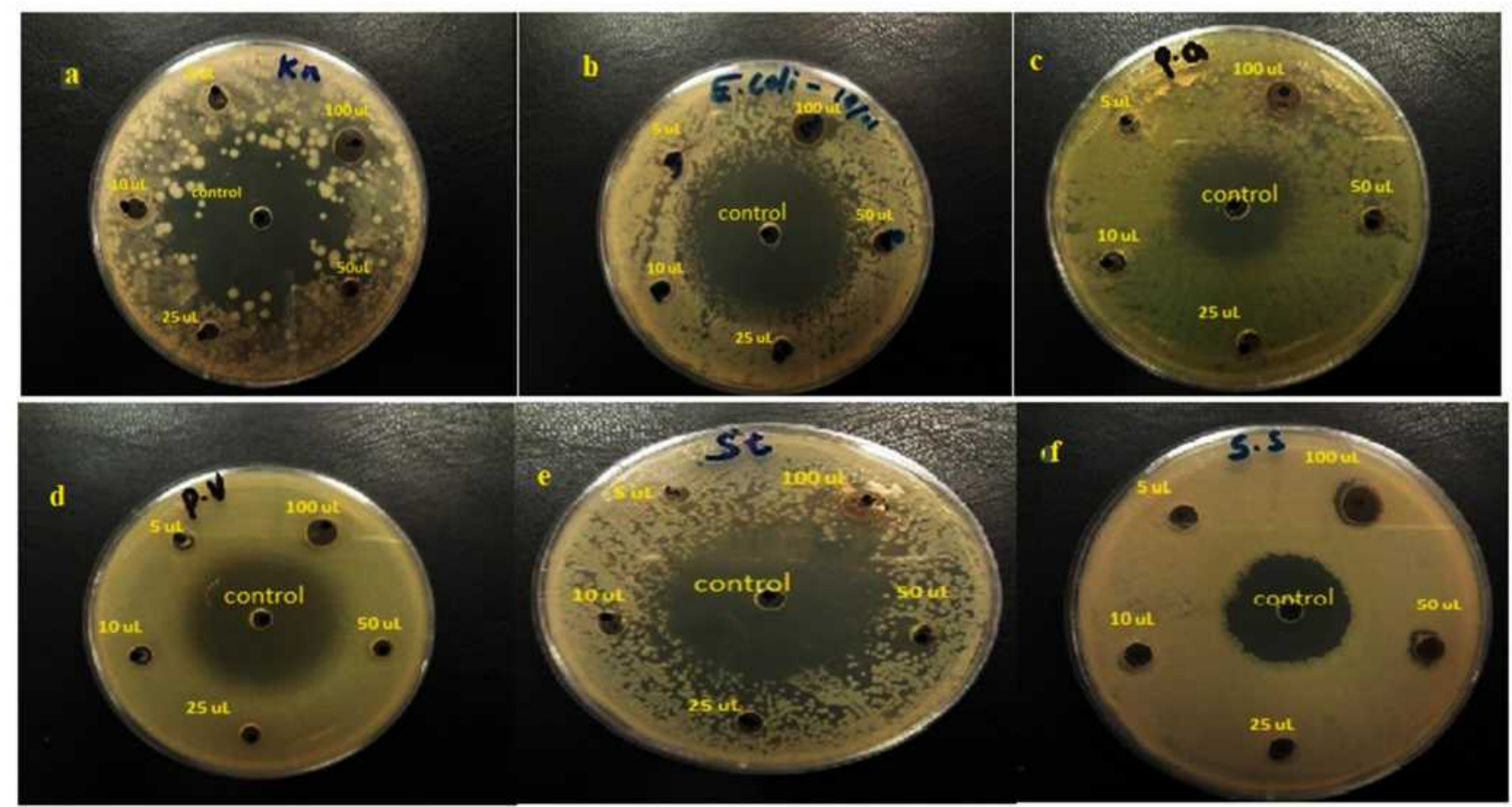

(a) K. pneumoniae (b) E. coli (c) P. aeruginosa (d) P. vulgaris (e) S. typhimurium (f) S. sonnei

Figure 7 Micrograph showing the diameter of zone of inhibition [mm] due to AME-AgNPs exposure to six Gram negative microbial pathogens. (A) K. pneumoniae, (B) E. coli, (C) P. aeruginosa, (D) P. vulgaris, (E) S. typhimurium and (F) S. sonnei. 


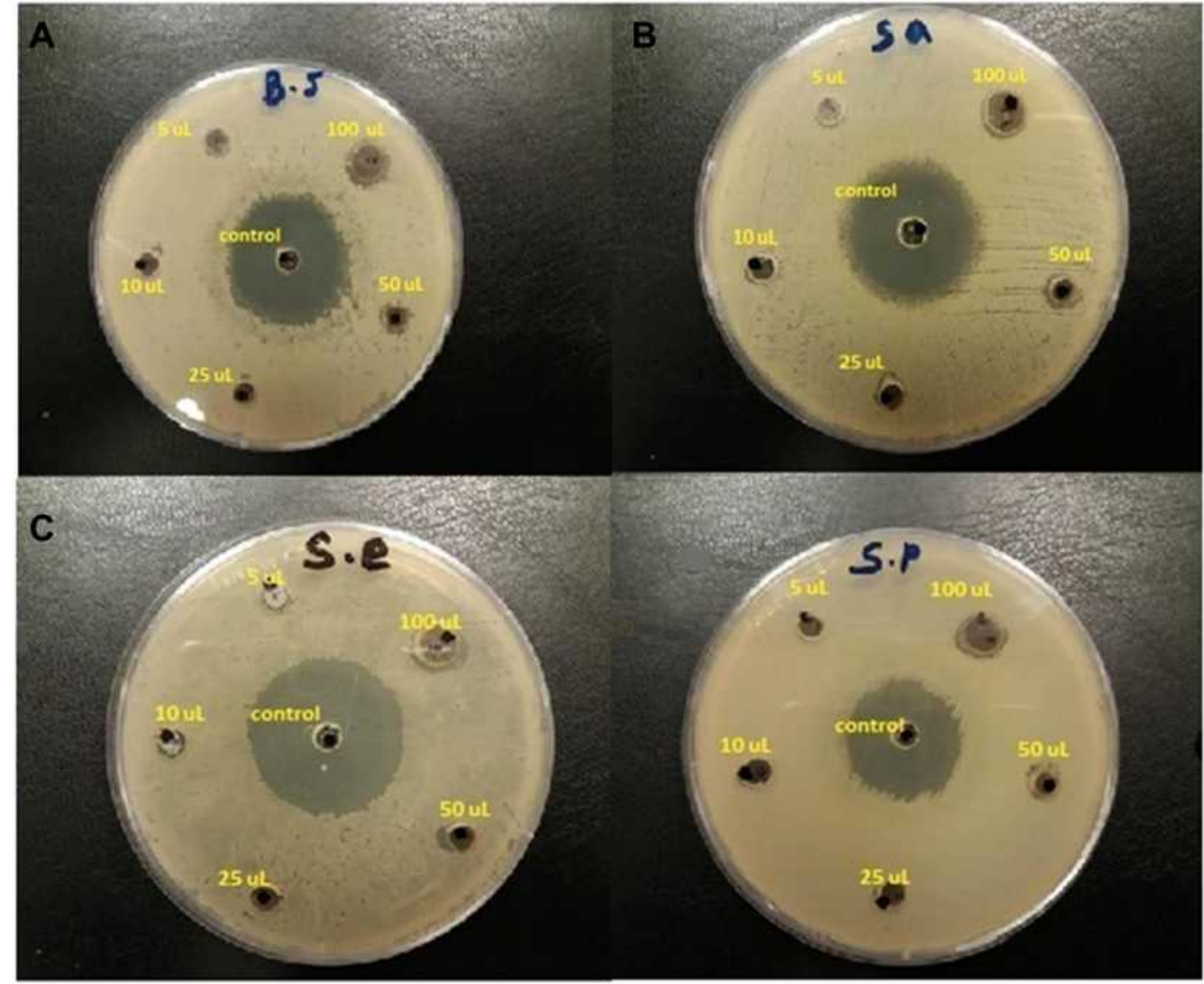

\section{A B. subtilis B $S$. aureus C S. epidermidis D S.pyogenes}

Figure 8 Micrograph showing the diameter of zone of inhibition [mm] due to AME-AgNPs exposure to four Gram positive microbial pathogens. (A) B. subtilis, (B) S. aureus, (C) S. epidermidis and (D) S. pyogenes.

nanomaterial. ${ }^{39}$ It has also been reported that the interaction of silver nanoparticles with phosphorylated or sulfur proteins present in the cell wall of bacteria destabilizes and depolarizes the bacterial cell membrane, affecting the integrity of the membrane and leakage of $\mathrm{H}^{+} .40$

The antibacterial mechanisms of action of AgNPs may be their interactions with the microbial membrane, which could lead to the rearrangement of membrane-bound organelles, destruction of the membrane and death of microbial pathogens. The mode of action of AgNPs against microbial pathogens has not been fully explored thus far. Recent studies have revealed that the mechanisms of action against microorganisms depend on the size, shape, stability and affinity of the NPs. ${ }^{41}$ Four different possible routes were reported for the antimicrobial mechanisms of action of AgNPs. These include (i) interactions between the AgNPs and the surface of the cell wall and membrane, (ii) AgNP penetration into the cell and damage to intracellular organelles, (iii) AgNP-induced cellular toxicity and oxidative stress caused by the generation of
ROS and free radicals and (iv) AgNP regulation of the signaling pathways that inhibit proliferation. ${ }^{42}$

It has been reported that AgNPs attached to the bacterial cell wall release $\mathrm{Ag}^{+}$through an oxidation process and react with phosphate, the thiol group of the amino acid cysteine, the amino acid glutamine, and carboxyl groups, causing bacterial death. ${ }^{43}$ Furthermore, the bacterial cell membrane could undergo oxidative changes induced by the AgNPs due to their possession of bioactive compounds, leading to cell death. The size of the AgNPs is also reported to influence the antibacterial action. In this study, the synthesized NPs were more or less spherical with an average size of $18.6 \mathrm{~nm}$, which also influenced the antibacterial action, as previously observed. $^{44}$ Because the AME-AgNPs exhibited good antibacterial activities, they could be used as broad-spectrum antibiotics. The small size of the NPs resulted in stronger interactions between the NPs and cells due to a larger surface area-to-mass ratio and greater versatility. ${ }^{45}$ Ultra-small and controllable NPs are effective for conducting 

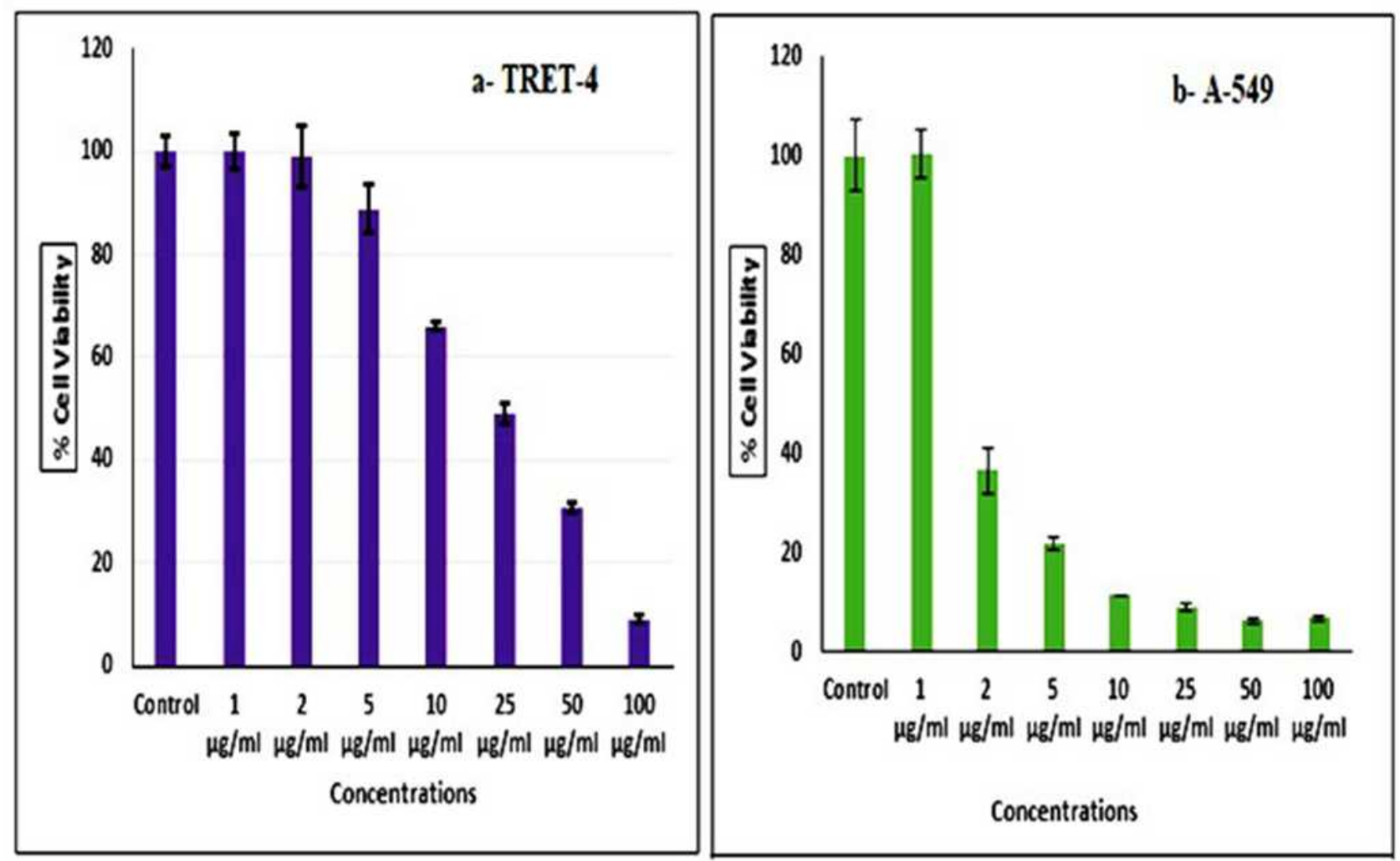

Figure 9 Cytotoxicity assessment by MTT assay. (A) TERT4 cell line and (B) A 549 cell lines exposed to AME-AgNPs at I-I00 mg/mL for 24 h. Images were taken using phase contrast inverted microscope at 20x magnification.

antimicrobial operations and combating intracellular bacteria. $^{46}$ The AgNPs synthesized in this study were small and could thus be used to develop effective and safe antibiotics.

\section{MTT Assay}

The cytotoxic effects of the nanoparticles on TERT-4 and A-549 cells are presented in Figure 9A and B. All the cells were treated with $1-100 \mu \mathrm{g} / \mathrm{mL}$ synthesized nanoparticles for $24 \mathrm{~h}$. The results showed that the synthesized nanoparticles decreased the viability of the A-549 and TERT-4 cells in a concentration-dependent manner. A cytotoxic response was observed even at low concentrations, ie, $2 \mu \mathrm{g} / \mathrm{mL}$ of the synthesized nanoparticles; however, more than $90 \%$ of the cells died at the highest concentration, ie, $100 \mu \mathrm{g} / \mathrm{mL}$. The percent cell viabilities at $2,5,10,25,50$ and $100 \mu \mathrm{g} / \mathrm{mL}$ of the synthesized nanoparticles were determined to be $59 \%$, $17 \%, 11 \%, 11 \%, 11 \%$ and $9 \%$, respectively, for the TERT-4 cells (Figure 9A) and 34\%, 15\%, 12\%, 11\%, 10\% and 9\%, respectively, for the A-549 cells (Figure 9B). For the three tested cancer cell lines, AME-AgNP concentrations of 25 and $50 \mu \mathrm{g} / \mathrm{mL}$ significantly reduced the cell viability $(P<0.05)$, and cell death at a dose of $100 \mu \mathrm{g} / \mathrm{mL}$ was very significant $(P<0.001)$ compared with that of the control (Table 2$)$.

The morphological changes observed in the TERT-4 and A-549 cells are shown in Figure 10A and B). Concentration-dependent effects were observed on the morphologies of A-549 and TERT-4 cells treated with $2-200 \mu \mathrm{g} / \mathrm{mL}$ synthesized nanoparticles for $24 \mathrm{~h}$. At concentrations of $2 \mu \mathrm{g} / \mathrm{mL}$ of the synthesized nanoparticles and higher, the cells became rounded and lost their typical

Table 2 The Percent Cell Viability for Two Different Cell Lines on Exposure with Different Concentration of AME-AgNPs

\begin{tabular}{|l|l|l|l|}
\hline \multicolumn{4}{|c|}{ Percent Cell viability \pm SD Different cell lines } \\
\hline S. No. & Concentrations $\mu \mathrm{g} / \mathrm{mL}$ & A-549 & TRET-4 \\
\hline 1 & Control & $100 \pm 0.47$ & $100 \pm 2.91$ \\
2 & $1 \mu \mathrm{g} / \mathrm{mL}$ & $101.7 \pm 2.61$ & $100.02 \pm 3.66$ \\
3 & $2 \mu \mathrm{gL}$ & $34.4 \pm 4.87$ & $99.1 \pm 5.92$ \\
4 & $5 \mu \mathrm{mL} / \mathrm{mL}$ & $15.7 \pm 2.11$ & $88.7 \pm 4.70$ \\
5 & $10 \mu \mathrm{g} / \mathrm{mL}$ & $12.25 .7 \pm 0.9$ & $66.1 \pm 0.84$ \\
6 & $25 \mu \mathrm{g} / \mathrm{mL}$ & $11.3 \pm 0.81$ & $49.0 \pm 1.95$ \\
7 & $50 \mu \mathrm{g} / \mathrm{mL}$ & $10.8 \pm 2.46$ & $30.7 \pm 0.96$ \\
8 & $100 \mu \mathrm{g} / \mathrm{mL}$ & $9.63 \pm 0.56$ & $9.3 \pm 0.8 \mathrm{I}$ \\
\hline
\end{tabular}




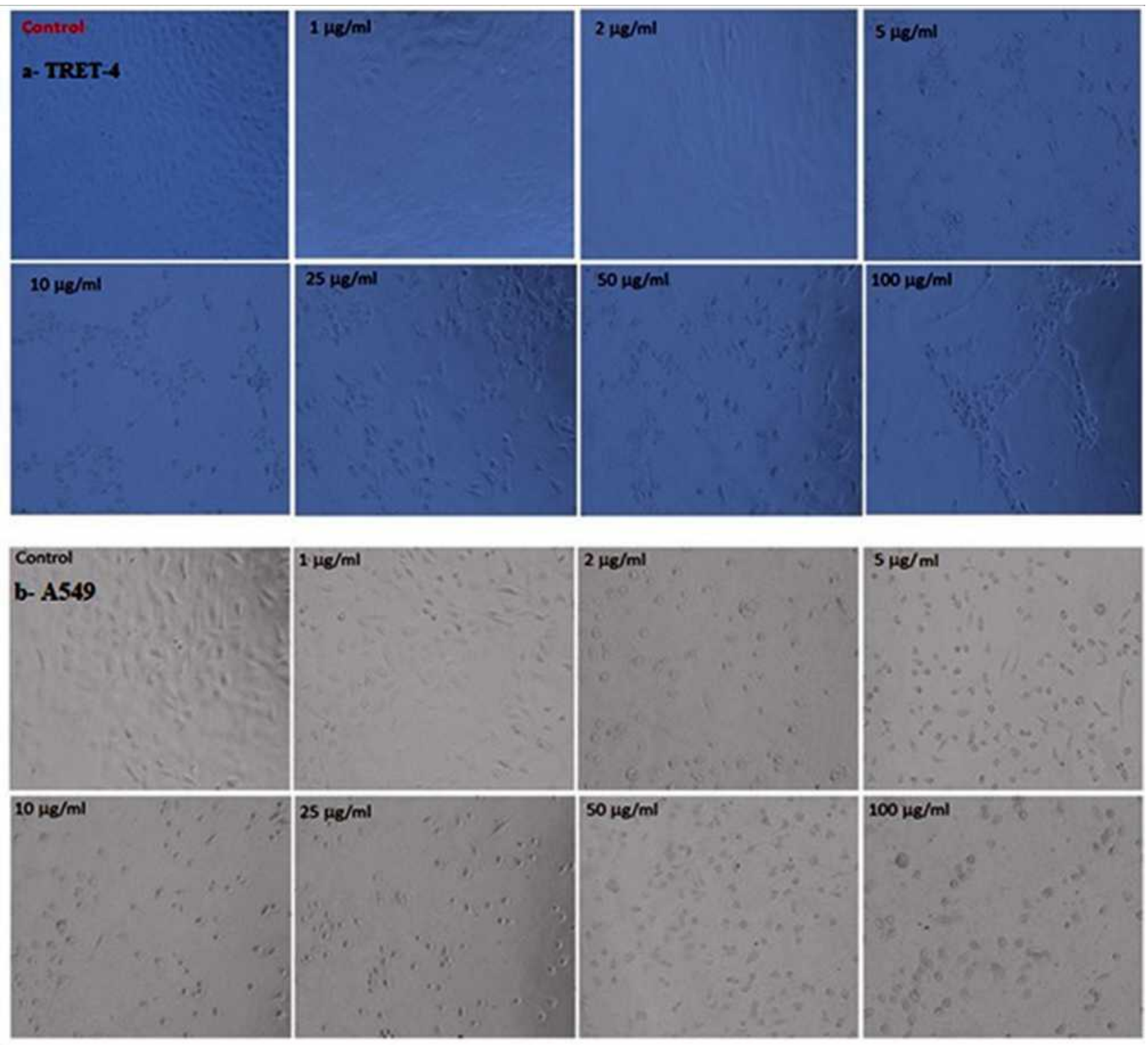

Figure 10 Morphological alterations in (A) TERT4 cell line and (B) A 549 cell lines exposed to AME-AgNPs at I-I00 mg/mL for 24 h. Images were taken using phase contrast inverted microscope at 20x magnification.

morphology. A careful observation of the photomicrograph of cells exposed to a $100 \mu \mathrm{g} / \mathrm{mL}$ dose showed hypertrophied cells with necrotic, condensed nuclei undergoing pyknosis. The $\mathrm{IC}_{50}$ values of the synthesized AgNPs and the standard drug 5-fluorouracil against A-549 and TERT-4 (Table 3) confirmed the tumor-inhibiting effect of the synthesized nanoparticles.

The cytotoxicity of AgNPs to cell lines was reported to be due to the cellular uptake of nanoparticles through pinocytosis and endocytosis. ${ }^{47}$ It has been reported that a cell viability below $50 \%$ indicates that NPs are cytotoxic. $^{48,49}$ The size of the nanoparticles and the plant extract surface coating promoted the cytotoxicity. ${ }^{50,51}$ AgNPs trigger an increase in intracellular ROS, and reactive hydroxyl radicals damage DNA, which results in cell death. ${ }^{52}$ AgNPs coated with plant bioconstitutents induce

Table $3 I C_{50}$ Concentration of AME-AgNPs and Standard Drug on Human Cell Lines

\begin{tabular}{|l|l|l|l|}
\hline & $\begin{array}{l}\text { Cell } \\
\text { Lines }\end{array}$ & $\begin{array}{l}\text { AME- } \\
\text { AgNPs }\end{array}$ & $\begin{array}{l}\text { Control } \\
\text { [5-Fluorouracil] }\end{array}$ \\
\hline $\begin{array}{l}\mathrm{IC}_{50} \mu \mathrm{g} / \mathrm{mL} / \text { Cell } \\
\text { Lines-NPs }\end{array}$ & A-549 & $1.74 \mu \mathrm{g} / \mathrm{mL}$ & $0.763 \mu \mathrm{g} / \mathrm{mL}$ \\
\cline { 2 - 4 } & TRET-4 & $1.65 \mu \mathrm{g} / \mathrm{mL}$ & $0.781 \mu \mathrm{g} / \mathrm{mL}$ \\
\hline
\end{tabular}


oxidative stress, leading to apoptosis via caspase-mediated and mitochondria-dependent pathways. ${ }^{53,54}$ Nanoparticles induce hydroxyl radical formation and are highly toxic to cancer cells. $^{55,56}$

The interaction of AgNPs with cells induces the hyperproduction of ROS, leading to mitochondrial dysfunction and degenerative changes in the expression of some antiapoptotic (Bcl-2) and pro-apoptotic (Bax) genes and proteins present in the mitochondria. As a result, the pro-apoptotic mitochondrial protein $\mathrm{Cyt} \mathrm{C}$ is released into the cytosol and induces apoptosis by activating the apoptotic proteins caspase- 9 and caspase- $3 .{ }^{57-60}$

\section{Conclusions}

In the intensive search for effective green synthesized nanoparticles, several biological entities have been screened. In this study, extracts of the flowers of $A$. esculentus were used as a moderating agent to synthesize AgNPs. The synthesis of the AgNPs was confirmed by different characterizations. The morphological nature of the synthesized material was predominantly spherical and less aggregated with an average size of less than $19 \mathrm{~nm}$, as determined by TEM. The NPs exhibited antimicrobial properties against all the tested grampositive and gram-negative microbial pathogens. However, gram-negative bacterial growth was more inhibited than gram-positive bacterial growth. The MIC value for $P$. vulgaris was less than that for the other bacteria. The MBC value was low for $S$. pyogenes. Tests of the impact of the synthesized AME-AgNPs on tumor cell lines revealed reasonable effects. The $\mathrm{IC}_{50}$ values of the NPs for A-549 and TERT-4 cells were compared with those of a standard drug. Cytotoxicity and apoptosis were studied by microscopically observing the synthesized nanoparticles, and necrosis, hypertrophy, pycnotic nuclei and nuclear disintegration were detected. This study provides valuable information about the antibacterial and anticancer efficacy of okra flower extract-mediated AgNPs. The nanoparticles can be further subjected to toxicity assays.

\section{Acknowledgment}

The authors extend their appreciation to the Deanship of Scientific Research at King Saud University for funding the work through the research group project number RGP-023.

\section{Disclosure}

Sandhanasamy Devanesan reports a patent US10059601B1 issued. The authors are declaring no other conflicts of interest.

\section{References}

1. AlSalhi MS, Devanesan S, Alfuraydi AA, et al. Green synthesis of silver nanoparticles using Pimpinella anisum seeds: antimicrobial activity and cytotoxicity on human neonatal skin stromal cells and colon cancer cells. Int J Nanomed. 2016;11:4439-4449. doi:10.2147/ IJN.S113193

2. Devanesan S, AlSalhi MS, Balaji RV, et al. Antimicrobial and cytotoxicity effects of synthesized silver nanoparticles from Punica granatum peel extract. Nanoscale Res Lett. 2018;13(1):315. doi:10.1186/ s11671-018-2731-y

3. Bindhu MR, Umadevi M, Esmail GA, Al-Dhabi NA, Arasu MV. Green synthesis and characterization of silver nanoparticles from Moringa oleifera flower and assessment of antimicrobial and sensing properties. J Photochem Photobiol B. 20(205):111836.

4. Devanesan S, Ponmurugan K, AlSalhi MS, Al-Dhabi NA. Cytotoxic and antimicrobial efficacy of silver nanoparticles synthesized using a traditional phytoproduct, Asafoetida Gum. Int $J$ Nanomed. 2020;15:4351-4362. doi:10.2147/IJN.S258319

5. Al-Ansari MM, Dhasarathan P, Ranjitsingh AJA, Al-Humaid LA. Ganoderma lucidum inspired silver nanoparticles and its biomedical applications with special reference to drug resistant Escherichia coli isolates from CAUTI. Saudi J Biol Sci. 2020;27:2993-3002. doi:10.1016/j.sjbs.2020.09.008

6. Devanesan S, AlSalhi MS, Vishnubalaji R, et al. Rapid biological synthesis of silver nanoparticles using plant seed extracts and their cytotoxicity on colorectal cancer cell lines. $J$ Clust Sci. 2014;28:595-605. doi:10.1007/s10876-016-1134-4

7. Khan SA, Shahid S, Ayaz A, Alkahtani J, Elshikh MS, Riaz T. Phytomolecules-coated nio nanoparticles synthesis using abutilon indicum leaf extract: antioxidant, antibacterial, and anticancer activities. Int J Nanomed. 2021;16:1757-1773. doi:10.2147/IJN.S294012

8. Khan SA, Shahid S, Lee CS. Green synthesis of gold and silver nanoparticles using leaf extract of clerodendrum inerme; characterization, antimicrobial, and antioxidant activities. Biomolecules. 2020;10(6):835. doi:10.3390/biom10060835

9. Khan SA, Shahid S, Hanif S, Almoallim HS, Alharbi SA, Sellami H. Green synthesis of chromium oxide nanoparticles for antibacterial, antioxidant anticancer, and biocompatibility activities. Int J Mol Sci. 2021;22(2):502. doi:10.3390/ijms22020502

10. Patil SP. Calotropis gigantea assisted green synthesis of nanomaterials and their applications: a review. Beni-Suef Univ J Basic Appl Sci. 2020;9:14. doi:10.1186/s43088-020-0036-6

11. Elhawary S, EL-Hefnawy H, Alzahraa FA. Green synthesis of silver nanoparticles using extract of Jasminum officinal $l$. leaves and evaluation of cytotoxic activity towards bladder (5637) and breast cancer (MCF-7) cell lines. Int J Nanomed. 2020;15:9771-9781. doi:10.2147/ IJN.S269880

12. Hemeg HA. Nanomaterials for alternative antibacterial therapy. Int J Nanomed. 2017;12:8211-8225. doi:10.2147/IJN.S132163

13. Rakesh Kumar B, Alemu F, Archana B, Azamal H. Biogenic fabrication of nanomaterials from flower-based chemical compounds, characterization and their various applications: a review. Saudi J Biol Sci. 2020;27:2551-2562. doi:10.1016/j.sjbs.2020.05.012

14. Bharathi D, Diviya JM, Vasantharaj S, Bhuvaneshwari V. Biosynthesis of silver nanoparticles using stem bark extracts of Diospyros montana and their antioxidant and antibacterial activities. J Nanostruct Chem. 2018;8:83-92. doi:10.1007/s40097-018-0256-7

15. Bharathi D, Vasantharaj S, Bhuvaneshwari V. Green synthesis of silver nanoparticles using Cordia dichotoma fruit extract and its enhanced antibacterial, anti-biofilm and photo catalytic activity. Mater Res Express. 2018;5:055404. doi:10.1088/2053-1591/aac2ef

16. Aravind M, Awais A, Ikram A, et al. Critical green routing synthesis of silver NPs using jasmine flower extract for biological activities and photocatalytical degradation of methylene blue. J Environ Chem Eng. 2021;9:104877. doi:10.1016/j.jece.2020.104877 
17. Qhtani M, El-Debaiky S, Sayed M. Antifungal and cytotoxic activities of biosynthesized silver, zinc and gold nanoparticles by flower extract of Rhanterium epapposum. Open $J$ Appl Sci. 2020;10:663-674. doi:10.4236/ojapps.2020.1011046

18. Singh P, Chauhan V, Tiwari BK, et al. Overview on Okra Abelmoschus esculentes and its importance as a nutritive vegetable in the world. IJPBS. 2014;4:227-233.

19. Mollick MR, Bhowmick B, Mondal D, et al. Anticancer (in vitro) and antimicrobial effect of gold nanoparticles synthesized using Abelmoschus esculentus (L.) pulp extract via a green route. RSC Adv. 2014;4:37838-37848. doi:10.1039/C4RA07285E

20. Somasundaram G, Rajan J. Effectual Role of Abelmoschus esculentus (Okra) extract on morphology, microbial and photocatalytic activities of CdO Tetrahedral Clogs. J Inorg Organomet Polym Mater. 2017;28:152-167. doi:10.1007/s10904-017-0695-5

21. Sabouri Z, Akbari A, Ali HH, Hashemzadeh A, Darroudi M. Ecofriendly biosynthesis of nickel oxide nanoparticles mediated by okra plant extract and investigation of their photocatalytic, magnetic, cytotoxicity, and antibacterial properties. $J$ Clust Sci. 2019;30:1425-1434. doi:10.1007/s10876-019-01584-x

22. Gu L, Hong F, Fan K, et al. Integrated Network Pharmacology Analysis and Pharmacological Evaluation to Explore the Active Components and Mechanism of Abelmoschus manihot (L.). Medik on renal fibrosis. Drug Des Devel Ther. 2020;14:4053-4067.

23. CLSI. Methods for dilution antimicrobial susceptibility tests $f$ or bacteria that grow aerobically; approved standard-Ninth Edition. CLSI document M07-A9. Wayne, PA: Clinical and Laboratory Standards Institute; 2012.

24. Mosmann T. Rapid colorimetric assay for cellular growth and survival: application to proliferation and cytotoxicity assays. $J$ Immunol Methods. 1983;65:55-63. doi:10.1016/0022-1759(83)90303-4

25. Brus L. Electronic wave functions in semiconductor clusters: experiment and theory. J Phys Chem. 1986;90:2555-2560. doi:10.1021/ j100403a003

26. Maheshwaran G, Nivedhitha bharathi A, Malai Selvi M, Krishna Kumar M, Mohan Kumar R, Sudhahar S. Green synthesis of Silver oxide nanoparticles using Zephyranthes Rosea flower extract and evaluation of biological activities. $J$ Environ Chem Eng. 2020;8:104137. doi:10.1016/j.jece.2020.104137

27. Fatimah I, Hidayat H, Nugroho BH, Husein S. Ultrasound-assisted biosynthesis of silver and gold nanoparticles using Clitoria ternatea flower. S Afr J Chem Eng. 2020;34:97-106.

28. Wei S, Wang Y, Tang Z, et al. A novel green synthesis of silver nanoparticles by the residues of Chinese herbal medicine and their biological activities. RSC Adv. 2021;11:1411. doi:10.1039/ D0RA08287B

29. Sundeep D, Kumar V, Rao T, Rao PSS, Ravikumar RVSS, Gopala Krishna A. Green synthesis and characterization of Ag nanoparticles from Mangifera indica leaves for dental restoration and antibacterial applications. Prog Biomater. 2017;6:57-66. doi:10.1007/s40204-0170067-9

30. Peterson VK, Papadakis CM. Functional materials analysis using in situ and in operando X-ray and neutron scattering. IUCrJ. 2015;2:292-304. doi:10.1107/S2052252514026062

31. Swilam N, Nematallah KA. Polyphenols profile of pomegranate leaves and their role in green synthesis of silver nanoparticles. Sci Rep. 2020;10:14851. doi:10.1038/s41598-020-71847-5

32. Singh C, Kumar J, Kumar P, et al. Green synthesis of silver nanoparticles using aqueous leaf extract of Premna integrifolia (L.) rich in polyphenols and evaluation of their antioxidant, antibacterial and cytotoxic activity. Biotechnol. Biotechnol Equip. 2019;33:359-371. doi:10.1080/13102818.2019.1577699

33. Ibrahim AA, Mohamed MI, Gehan AE. Evaluation of green synthesis of Ag nanoparticles using Eruca sativa and Spinacia oleracea leaf extracts and their antimicrobial activity. Iran $J$ Biotechnol. 2014;12:50-55.
34. Rautela A, Rani J, Debnath DM. Green synthesis of silver nanoparticles from Tectona grandis seeds extract: characterization and mechanism of antimicrobial action on different microorganisms. J Anal Sci Technol. 2019;10:5.

35. Hamouda RA, Hussein MH, Abo-elmagd RA, Bawazir SS. Synthesis and biological characterization of silver nanoparticles derived from the cyanobacterium Oscillatoria limnetica. Sci Rep. 2019;9:13071.

36. Tavares TD, Antunes JC, Padrão J, et al. Activity of specialized biomolecules against gram-positive and gram-negative bacteria. Antibiotics (Basel, Switzerland). 2020;9(6):314. doi:10.3390/ antibiotics 9060314

37. Xuan NP, Hoa NA, Ngan TA. Green synthesis and antibacterial activity of HAp@Ag nanocomposite using Centella asiatica (L.) Urban extract and eggshell. Int J Biomater. 2020;2020:8841221.

38. Qais FA, Shafiq A, Khan HM, et al. Antibacterial effect of silver nanoparticles synthesized using Murraya koenigii (L.) against multidrug-resistant pathogens. Ahmad Bioinorg Chem Appl. 2019;2019:4649506.

39. Salem SS, El-Belely EF, Niedbała G, et al. Bactericidal and in-vitro cytotoxic efficacy of silver nanoparticles (Ag-NPs) fabricated by endophytic actinomycetes and their use as coating for the textile fabrics. Nanomaterials (Basel). 2020;10:2082. doi:10.3390/nano10102082

40. Zorraquín-Peña I, Cueva C, Bartolomé B, Moreno-Arribas MV. Silver nanoparticles against foodborne bacteria. effects at intestinal level and health limitations. Microorganisms. 2020;8:132. doi:10.3390/microorganisms 8010132

41. Park SB, White SB, Steadman CS, et al. Silver-coated magnetic nanocomposites induce growth inhibition and protein changes in foodborne bacteria. Sci Rep. 2019;9(1):17499. doi:10.1038/s41598019-53080-x

42. Dakal TC, Kumar A, Majumdar RS, Yadav V. Mechanistic basis of antimicrobial actions of silver nanoparticles. Front Microbiol. 2016;7:1831. doi:10.3389/fmicb.2016.01831

43. Pryshchepa O, Pomastowski P, Buszewski B. Silver nanoparticles: synthesis, investigation techniques, and properties. Adv Colloid Interface Sci. 2020;284:102246. doi:10.1016/j.cis.2020.102246

44. Gabrielyan L, Badalyan H, Gevorgyan A, Trchounian A. Comparable antibacterial efects and action mechanisms of silver and iron oxide nanoparticles on Escherichia coli and Salmonella typhimurium. Sci Rep. 2020;10:13145. doi:10.1038/s41598-020-70211-x

45. Wang $\mathrm{L}, \mathrm{Hu} \mathrm{C}$, Shao L. The antimicrobial activity of nanoparticles: present situation and prospects for the future. Int $J$ Nanomed. 2017;12:1227-1249. doi:10.2147/IJN.S121956

46. Ranghar S. Nanoparticle-based drug delivery systems: promising approaches against infections. Braz Arch Biol Technol. 2012;57:209-222. doi:10.1590/S1516-89132013005000011

47. Pellissari CVG, Vergani CE, Longo E, et al. In vitro toxic effect of biomaterials coated with silver tungstate or silver molybdate microcrystals. Nanometer. 2020;2020:2971827.

48. Baker MA, Assis SL, Higa OZ, Costa I. Nanocomposite hydroxyapatite formation on a Ti-13Nb-13Zr alloy exposed in a MEM cell culture medium and the effect of $\mathrm{H} 2 \mathrm{O} 2$ addition. Acta Biomater. 2009;5:63-75. doi:10.1016/j.actbio.2008.08.008

49. Bin-Jumah M, Al-Abdan M, Albasher G, Alarifi S. Effects of green silver nanoparticles on apoptosis and oxidative stress in normal and cancerous human hepatic cells. Int J Nanomed. 2020;15:1537-1548. doi:10.2147/IJN.S239861

50. Mao BH, Chen ZY, Wang YJ, Yan SJ. Silver nanoparticles have lethal and sublethal adverse effects on development and longevity by inducing ROS-mediated stress responses. Sci Rep. 2018;8:2445. doi:10.1038/s41598-018-20728-z

51. Majid SJ, Aya AH, Ghassan MS, et al. Green synthesis of silver nanoparticles from Eriobotrya japonica extract: a promising approach against cancer cells proliferation, inflammation, allergic disorders and phagocytosis induction. Artif Cells Nanomed Biotechnol. 2021;49:48-60. doi:10.1080/21691401.2020.1867152 
52. Skomorokhova EA, Sankova TP, Orlov IA, et al. Size-dependent bioactivity of silver nanoparticles: antibacterial properties, influence on copper status in mice, and whole-body turnover. Nanotechnol Sci Appl. 2020;13:137-157. doi:10.2147/NSA.S287658

53. Datkhile KD, Durgawale PP, Patil MN. Biogenic silver nanoparticles are equally Cytotoxic as Chemically Synthesized silver nanoparticles. Biomed Pharmacol J. 2017;10. doi:10.13005/bpj/1114]

54. Mie R, Samsudin MW, Din L, Ahmad A, Ibrahim N, Adnan S. Synthesis of silver nanoparticles with antibacterial activity using the lichen Parmotrema praesorediosum. Int $J$ Nanomed. 2014;9 (1):121-127. doi:10.2147/IJN.S52306

55. Edis Z, Wang J, Waqas MK, Ijaz M, Ijaz M. Nanocarriers-mediated drug delivery systems for anticancer agents: an overview and perspectives. Int J Nanomed. 2021;16:1313-1330. doi:10.2147/IJN. S289443

56. Devanesan S, Jeyamala M, AlSalhi MS, Umamaheswari M, Ranjithsingh AJA. Antimicrobial and Anticancer properties of Carica papaya leaves derived di-methyl flubendazole mediated silver nanoparticles. $J$ Infect Public Health. 2021. doi:10.1016/j. jiph.2021.02.004
57. Zhen X, Qi F, Min W, Huange Z, Yingying L, Songlin Z. Front. Green biosynthesized silver nanoparticles with aqueous extracts of Ginkgo biloba induce apoptosis via mitochondrial pathway in cervical cancer cells. Oncol. 2020;10:2282.

58. Abdellatif AAH, Rasheed Z, Alhowail AH, et al. Silver citrate nanoparticles inhibit PMA-Induced TNF $\alpha$ Expression via Deactivation of NF- $\kappa \mathrm{B}$ activity in human cancer cell-lines, MCF-7. Int J Nanomed. 2020;15:8479-8493. doi:10.2147/IJN.S274098

59. Taha ZK, Hawar SN, Sulaiman GM. Extracellular biosynthesis of silver nanoparticles from Penicillium italicum and its antioxidant, antimicrobial and cytotoxicity activities. Biotechnol Lett. 2019;41:899-914. doi:10.1007/s10529-019-02699-x

60. Jabir MS, Saleh YM, Sulaiman GM, et al. Green synthesis of silver nanoparticles using annona muricata extract as an inducer of apoptosis in cancer cells and inhibitor for NLRP3 inflammasome via enhanced autophagy. Nanomaterials (Basel). 2021;11(2):384. doi:10.3390/nano11020384
International Journal of Nanomedicine

\section{Publish your work in this journal}

The International Journal of Nanomedicine is an international, peerreviewed journal focusing on the application of nanotechnology in diagnostics, therapeutics, and drug delivery systems throughout the biomedical field. This journal is indexed on PubMed Central, MedLine, CAS, SciSearch ${ }^{\mathbb{R}}$, Current Contents ${ }^{\mathbb{R}} /$ Clinical Medicine, $^{-}$

\section{Dovepress}

Journal Citation Reports/Science Edition, EMBase, Scopus and the Elsevier Bibliographic databases. The manuscript management system is completely online and includes a very quick and fair peer-review system, which is all easy to use. Visit http://www.dovepress.com/ testimonials.php to read real quotes from published authors. 